\title{
Equity Culture and the Distribution of Wealth"
}

\author{
Yannis Bilias \\ Athens University of Economics and Business and CFS \\ Dimitris Georgarakos
European Central Bank, Goethe University Frankfurt and CFS \\ Michael Haliassos \\ Goethe University Frankfurt, CFS and CEPR
}

April 4, 2013

\begin{abstract}
Is wider access to stockholding opportunities related to reduced wealth inequality, given that it creates challenges for small and less sophisticated investors? Counterfactual analysis is used to study the influence of changes in the US stockholder pool and economic environment, on the distribution of stock and net household wealth during a period of dramatic increase in stock market participation. We uncover substantial shifts in stockholder pool composition, favoring smaller holdings during the 1990s upswing but larger holdings around the burst of the Internet bubble. We find no evidence that widening access to stocks was associated with reduced net wealth inequality.
\end{abstract}

Keywords: Household finance; stockholding; financial literacy; wealth distribution.

JEL Codes: E21, G11

\footnotetext{
\# We thank Richard Blundell, Chris Carroll, Gikas Hardouvelis, Dirk Krueger, José Machado, Miquel Pellicer, Luigi Pistaferri, Susan Rohwedder, Gregory Siourounis, Arthur van Soest, Jonathan Skinner, Nick Souleles, Maarten van Rooij, Paul Söderlind, Steve Zeldes, participants at the NBER Summer Institute, the Mannheim RTN Conference, the Utrecht Netspar conference; and seminar participants at Aberdeen, Athens University of Economics and Business, Central European University in Budapest, Frankfurt, Netherlands Central Bank, Oxford, Piraeus, and St. Gallen for very useful comments. We are grateful to NETSPAR for financial support through a competitive research grant. This work has also been supported by the Center for Financial Studies under Research Program 'Household Wealth Management', while early stages were supported by the European Community's Human Potential Program.

Corresponding author: M. Haliassos, School of Economics and Business, Goethe University Frankfurt, Grueneburgplatz 1, PF H32, D-60323 Frankfurt am Main, Germany
} 


\section{Introduction}

Household investments in risky assets, especially direct and indirect stock holdings, grew substantially between the late 1980 s and 2001 in the US. ${ }^{1}$ By early 2000 s about half of households had invested in stocks, partly in response to stockholding opportunities introduced through individual retirement accounts and defined contribution pension plans. ${ }^{2}$

A sizeable expansion of the stockholder base, such as the one recorded in the US throughout the 1990s, is often thought of as facilitating wealth enhancement and reduction in wealth inequality by widening access to the equity premium. However, stocks are complicated and management-intensive financial instruments. As a result, they tend to create challenges, especially for households entering the stock market with limited resources, experience, information, and financial sophistication. Indeed, if enough unsophisticated investors enter and jeopardize their limited savings previously held in safe accounts, then increased access might result in a more unequal distribution of wealth.

Existing literature has established that certain household characteristics (e.g. higher wealth and education) increase the likelihood of stock market participation. ${ }^{3}$ A largely unexplored implication of this is that, when stockholding participation spreads, the composition of the stockholder pool in terms of investors' characteristics and of their respective tendencies to allocate wealth to stocks can also change. A natural candidate episode for studying such changes and their repercussions on wealth inequality is the period 1989-2001 in the US, that witnessed a continuous expansion of the stockholder pool in the face of dramatic stock price increases followed by the burst of the internet bubble.

\footnotetext{
${ }^{1}$ For participation trends in the United States since the 1980s, see Bertaut and Starr-McCluer (2002). Christelis, Georgarakos and Haliassos (2013) examine such links for 13 different countries, while they study patterns for the different stockholding modes available in the US in CGH (2011).

${ }^{2}$ The role of defined contribution pension plans, especially 401(k) plans, as a vehicle for spreading stock market participation during the boom is stressed in an Investment Company Institute and Securities Industry Association report entitled "Equity Ownership in America, 2005".

${ }^{3}$ See, for example, Haliassos and Bertaut (1995), Cocco, Gomes and Maenhout (2005), Heaton and Lucas (2000), Gollier (2001), Campbell and Viceira (2002), Haliassos and Michaelides (2003), and Gomes and
} 
In this paper, we use three waves of the US Survey of Consumer Finances (SCF) between 1989 and 2001 that record an increase in stock market participation and distinguish between the stock market upswing $(1989,1998)$ and the aftermath of the downswing $(2001){ }^{4}$ We first employ econometric methods of counterfactual analysis to uncover changes in the composition of the US stockholder pool over these periods, as well as their contribution to changes in the entire distribution of stockholding levels. Then, we examine the contribution of stockholding levels to changes in net wealth inequality over this important period. ${ }^{5}$

We find evidence that during the stock market upswing, there was a shift in the composition of the stockholder pool, in terms of characteristics, attitudes, and practices, that were more conducive to smaller stockholding levels. Yet, entries and exits around the burst of the internet bubble resulted, by 2001, in a stockholder pool with owner characteristics that favored more sizeable stock holdings. We estimate that a significant part of this change refers to financial attitudes and practices of the stockholder pool likely to be linked to financial literacy and sophistication.

Subsequently, we show that, over this period, inequality in stock holdings became quantitatively important for overall net wealth inequality, despite the relatively small share of stocks in household wealth. We find this to be in contrast with the limited importance of the typically largest component of wealth, namely primary residence. Notwithstanding the importance of stocks, we do not find evidence that widening access to the stock market during this period, notably through the spread of defined contribution plans and individual

Michaelides (2004). Behavioral finance perspectives to the issue of stockholding are reviewed by Barberis and Thaler (2003).

${ }^{4}$ According to the SCF, stock market participation peaked in 2001 (51.9\%) relative to only $31.8 \%$ in 1989. Stockholding rates in subsequent waves were relatively stable or somewhat declined: $48.6 \%$ in $2004,51.2 \%$ in 2007, and $49.8 \%$ in 2010.

${ }^{5}$ Wealth inequality is of interest both in its own right and because households at different points of the wealth distribution tend to exhibit different financial behavior. Hurst and Lusardi (2004) have documented that a positive relationship between wealth and entry into entrepreneurship can be found only at the top five percentiles of the wealth distribution. Carroll (2001) showed that richer households are not simply blown-up versions of poorer households. Wolff (1998) shows that only the top 20 percent of households enjoys higher 
retirement accounts, was associated with a progressively less unequal distribution of either stock wealth or net wealth.

Our findings have implications for different strands of recent literature. Theoretical literature on stock market participation and wealth inequality is rather limited, but already points to conflicting effects. Some papers emphasize that broadening access to an instrument offering an expected return premium would tend to reduce wealth inequality, while others point to ambiguities in the distributional effect arising from endogenous information acquisition (Arrow, 1987; Peress, 2004; Guvenen, 2006). ${ }^{6}$

There is cumulating evidence of differential financial sophistication and tendency of certain demographic groups to mishandle stock investments. Campbell (2006) argues that households with lower education and resources are more prone to 'investment mistakes' in terms of (non)participation, (under)diversification, and (lack of) debt refinancing. Poor understanding of finances has been shown to be more prevalent among females, minorities, and low-education households with limited finances and has been linked to lack of planning for retirement in data covering the older subset of the US population (Lusardi and Mitchell, 2007). In a recent study, stockholding participation was linked directly to indicators of financial literacy (Rooij, Lusardi, and Alessie, 2011). Feeling less financially competent has been shown more prevalent among females and those with lower education and has been linked to lack of international diversification in a study of US investors with at least $\$ 10,000$ in total investments (Graham, Harvey, and Huang, 2009).

\footnotetext{
mean net worth and financial wealth levels between 1983 and 1995, while the other groups undergo real wealth or income losses with the shortfall being more severe for the poor.

${ }^{6}$ Guvenen shows that limited stock market participation can account for much of US wealth inequality, which suggests that expanding participation should reduce wealth inequality. Ambiguities arise, however, even in stylized models once full financial information and sophistication are not taken for granted among all participating households (Peress, 2004). For effects of stock market participation regarding market volatility and stock market trading, see Pagano (1989), Allen and Gale (1994), Herrera (2001). For effects on the equity premium, see for example Heaton and Lucas (1999).
} 
Calvet, Campbell, and Sodini (2007) study a unique administrative data set on the population of Swedish households. They find that, although the median Sharpe ratio attained by Swedish participants is close to that attainable by a global equity index, there is significant cross-sectional variation, with low education and low-wealth households likely to exhibit lower Sharpe ratios. Recently, Van Rooij, Lusardi and Alessie (2012), using Dutch survey data, show that higher financial literacy is associated with higher levels of wealth in a given year. They attribute this to the role of financial literacy in facilitating access to stocks (i.e. an asset with wealth gaining potential) and thus to more efficient retirement planning.

The rest of the paper is organized as follows. Section 2 provides information on the data used and applies counterfactual decomposition techniques to investigate whether the spread of equity culture drew progressively smaller stockholders into the stockholder pool. Section 3 measures the contribution of various asset components to net total wealth inequality and its evolution over a period of growing participation that encompasses the stock market upswing followed by a downswing. Section 4 offers concluding remarks.

\section{Increased participation and the transformation of the stockholder pool}

Given the nature of our research questions, we use data from the SCF that span the entire population and not only a subset (such as older households interviewed in the Health and Retirement Study, or owners of sizeable investment accounts recorded in administrative data sources). The SCF exhibits two features that are key to our analysis: it oversamples the rich, who own the largest share of wealth; and it is not subject to top coding of wealthy households. ${ }^{7}$ As a result, the SCF covers almost the full range of the wealth distribution and can describe well the wealthy households who hold the bulk of stock wealth.

\footnotetext{
${ }^{7}$ SCF only omits the Forbes 400 for confidentiality reasons. By contrast, the Panel Study of Income Dynamics does not oversample the wealthy nor does it provide a disaggregation of different stockholding modes.
} 
In what follows, we use data from 1989, 1998, and 2001 SCF surveys to uncover the underlying transformation of the stockholding pool as participation spreads. We provide details on the data, asset categories, and variable definitions in a Data Appendix, available from the authors on request.

Existing household finance literature, shows consistently that certain characteristics make it more likely that a particular household will be drawn into the stockholder pool. We report in Table 1 marginal effects from probit regressions, for each of the three survey years, that control for a similar array of demographic and pecuniary characteristics to that employed in relevant studies (see, for example, the empirical contributions in Guiso, Haliassos and Jappelli, 2001). ${ }^{8}$ Consistent with existing literature, we find that being affluent, more educated, and less risk averse contribute to the probability of owning stocks (held directly and indirectly), controlling for other factors. ${ }^{9}$ These results imply that certain characteristics contribute to the probability of being a stockholder, and that the composition of the stockholder pool changes in general as stock market participation spreads.

In Table 2 we present summary statistics on three factors often considered as key for stock investments, namely education, income and (non-equity) net wealth. These statistics show notable changes in the composition of the stockholder pool, as it was expanding, both in absolute terms and relative to the population. While they do suggest an increase in the share of 'small' and less educated stockholders during the upswing, they fail to indicate a continuation of this trend through the downswing. Specifically, by 1998 the share of college graduates among equity holders was somewhat reduced to $46.8 \%$, while in the population it increased by almost 6 percentage points. In addition, both the mean and median non-

\footnotetext{
${ }^{8}$ In this paper, we try to avoid some pitfalls involved in automatic computation of marginal effects by standard econometric software, which have recently been emphasized. We explain how we overcome these problems in Appendix A.

${ }^{9}$ Receiving an inheritance is also strongly related to stock ownership, consistent with the Investment Company Institute and Securities Industry Association study entitled "Equity Ownership in America, which reports that of equity holders surveyed "more than one fifth own individual stock portfolios received as gifts or inheritances".
} 
investment income among equity holders is lower in 1998 compared to 1989, while in the population it is considerably higher, by $10 \%$ and $6 \%$, respectively. A similar picture emerges when we look at net wealth.

However, by 2001 college graduates among equity holders reach $49.6 \%$, an increase of almost 3 percentage points within just three years, while their population share remains unchanged. They also show significant increases at all percentiles of income and wealth distribution (for instance, median non equity net worth increased two times more among equity holders compared to the population). If anything, summary statistics suggest that the composition of stockholders shifted against 'small' investors during the downswing, despite increased participation.

\subsection{The Composition of the Stockholder Pool: Counterfactual Distributions}

Changes over time across the entire distribution of stockholding levels result partly from changes in the configuration of stockholder attributes and partly from changes in the value of holdings among households of a given configuration of characteristics. The latter can be mainly linked to the prevailing economic environment, including the level of the stock market prices in a given year or increased availability of defined contribution pension plans. Summary statistics or regression estimates of isolated household characteristics are not sufficient to distinguish the combined contribution of various characteristics to stockholding levels from that of the prevailing economic environment.

We use recent advances in counterfactual distributions to decompose observed changes in equity holdings into those arising from changes in the economic environment facing stockholders of given characteristics; and those resulting from changes in 
configuration of characteristics of the stockholder pool, as participation spreads. ${ }^{10}$ While the stock market went up and down during the entire period and it is natural for changes in market valuation to have affected equity holdings of stockholders with given characteristics, we are interested in seeing whether changes in the composition of the pool also contributed to observed changes in the distribution of equity holdings, from large to small, and in which direction.

We apply a variant of the counterfactual decomposition technique proposed by Machado and Mata (2005), described in Appendix B. We run a series of quantile regressions ${ }^{11}$ and we decompose the change in the distribution of equity holdings between two years into (i) a component due to changes in the coefficients on given stockholder characteristics at various percentiles of the stockholding distribution; and (ii) a component due to the change in the distribution of covariates, i.e. configuration of stockholder characteristics.

When comparing two different years, say 1998 to 1989, the relevant counterfactual distribution is the (logarithm of) equity holdings that stockholders in 1989 would have if they had experienced the same economic environment faced by stockholders in 1998. Formally, the difference between the 1998 and 1989 distributions of equity holdings at each percentile is decomposed into:

$$
f\left(y^{98}\right)-f\left(y^{89}\right)=\left\{f\left(y^{98}\right)-f^{*}\left(y ; X^{89} b^{98}\right)\right\}+\left\{f^{*}\left(y ; X^{89} b^{98}\right)-f\left(y^{89}\right)\right\}
$$

where $\mathrm{y}$ represents the $\log$ of equity wealth, $\mathrm{X}$ is the data matrix and $\mathrm{b}$ is a vector of estimated quantile regression coefficients evaluated at various percentiles. The difference in the first curly brackets represents the contribution of household characteristics to the overall

\footnotetext{
${ }^{10}$ Such techniques have been broadly used in the labor literature to decompose observed changes in the income distribution into changes in labor market conditions and changes in characteristics of the labor force. For a recent study on trends in US wage inequality in the last forty years see Autor, Katz and Kearney (2008). Christelis, Georgarakos and Haliassos (2013) have used these techniques to decompose differences in household portfolios between two countries into differences in characteristics and differences in economic environments faced by households of similar characteristics that live in different countries.
} 
difference between the 1998 and 1989 distributions of equity holdings ('covariate effects') for given economic environment. The difference in the second curly brackets measures the contribution of differences in economic environment facing households of given characteristics ('coefficient effects').

Coefficient and covariate effects for 1998-1989 are presented in Figure 1a and are statistically significant across percentiles, based on bootstrapped standard errors not reported here. Differences in distributions of equity holdings over this period are mainly driven by coefficient effects, and these become progressively more important at higher percentiles of the distribution. This is consistent with the exceptionally strong upward movement of stock market indices over this period, that allowed owners of given characteristics to exhibit much larger stock holdings in 1998 compared to 1989.

On the other hand, covariate effects are negative, implying that the 1989 stockholder pool would have generated even higher equity holdings under the 1998 economic environment than those that were actually observed among 1998 stockholders. In other words, the distribution of characteristics in the wider stockholder base at the end of the 1990s was not as conducive to high equity levels as the 1989 distribution.

Comparisons of 1989 to 1998 , the last period during the upswing for which SCF data are available, are consistent with the conjecture that the stockholder base underwent progressive dilution with smaller stockholders as participation grew during the upswing. However, when we compare 1998 with 2001, a period encompassing the stock market downturn, findings are reversed (Figure 2a). The decomposition is:

$$
f\left(y^{2001}\right)-f\left(y^{98}\right)=\left\{f\left(y^{2001}\right)-f^{*}\left(y ; X^{2001} b^{98}\right)\right\}+\left\{f^{*}\left(y ; X^{2001} b^{98}\right)-f\left(y^{98}\right)\right\}
$$

We find that coefficient effects are negative, as expected due to the decreased value of stocks following the downswing. However, covariate effects on equity holdings (displayed in the

\footnotetext{
${ }^{11}$ Regressors are the same as for the participation probits, presented in Table 1.
} 
second curly brackets) are positive and increasing beyond the $40^{\text {th }}$ percentile of the distribution of stock wealth. ${ }^{12}$ This implies that a stockholder pool with the configuration of stockholder characteristics of 2001 would have had higher equity levels in 1998, compared to those actually observed for 1998 stockholders. In turn, this suggests a tilt in the configuration of the stockholder pool towards larger holdings between 1998 and 2001, accompanying the continuing increase in participation.

These, combined with our findings for 1989-1998, point to the conclusion that the composition of the stockholder pool changed considerably with stock market conditions: during stock market upswings, the stockholder pool became more conducive to smaller holdings, but during downswings the balance was tilted towards bigger holdings, presumably by attracting predominantly larger investors and losing smaller ones. While the crosssectional nature of SCF does not allow us to observe entries and exits directly, recent work by Bilias, Georgarakos and Haliassos (2010) using panel data from the PSID and different techniques confirms that exits occurred despite the overall increase in participation, and that factors significantly contributing to exits included lower resources (income, non-stock net financial wealth, or net real wealth) and minority status, in good and in bad times; and poor health in bad times.

\subsection{A Role for Financial Attitudes and Practices?}

So far, we have used the terms 'large' or 'small' investor merely with reference to their likely level of stockholding, but without asking whether this level can be traced partly to a subset of characteristics that relates to financial attitudes and practices. This issue is relevant for understanding the implications of increased reliance on household decision making for managing riskier portfolios and providing for retirement.

${ }^{12}$ Both coefficient and covariate effects are statistically significant at percentiles above the $25^{\text {th }}$ according to 
We extend our counterfactual analysis in order to estimate the contribution of changes in configurations of financial attitudes and practices within the stockholder pool. We are conservative in what we include under attitudes and practices, in that we do not include factors such as education, which helps shape attitudes and inform practices but also determines the income process faced by the household. In this sense, we are likely - if anything - to underestimate the quantitative importance of financial attitudes and practices. We consider three factors, namely risk attitudes proxied by reported willingness to take more than average risk; reporting a long investment horizon (in excess of 10 years); and 'financial alertness' (defined as shopping around extensively for the best terms before making major borrowing and saving decisions).

We perform the following sequential decomposition:

$$
\begin{aligned}
f\left(y^{98}\right)-f\left(y^{89}\right) & =\left\{f\left(y^{98}\right)-f^{* *}\left(y ; X_{f}^{98}, X_{a}^{89}, b^{98}\right)\right\} \\
& +\left\{f^{* *}\left(y ; X_{f}^{98}, X_{a}^{89}, b^{98}\right)-f^{*}\left(y ; X^{89} b^{98}\right)\right\} \\
& +\left\{f^{*}\left(y ; X^{89} b^{98}\right)-f\left(y^{89}\right)\right\}
\end{aligned}
$$

where the counterfactual $f^{* *}$ represents the equity wealth distribution that would have prevailed in 1998 if the configuration of financial attitudes in the stockholder pool were distributed as in 1989. The term in the second curly bracket shows the relative contribution of other household characteristics.

Figure $1 \mathrm{~b}$ exhibits this decomposition of covariate effects for the 1989 to 1998 period. The blank area represents the effects of changes in financial attitudes and practices and implies a considerable contribution throughout the distribution of equity holdings.

Figure 2b carries out an analogous exercise for the period between 1998 and 2001. Here we use the following sequential decomposition: 


$$
\begin{aligned}
f\left(y^{2001}\right)-f\left(y^{98}\right) & =\left\{f\left(y^{2001}\right)-f^{*}\left(y ; X^{2001} b^{98}\right)\right\} \\
& +\left\{f^{*}\left(y ; X^{2001} b^{98}\right)-f^{* *}\left(y ; X_{f}^{98}, X_{a}^{2001}, b^{98}\right)\right\} \\
& +\left\{f^{* *}\left(y ; X_{f}^{98}, X_{a}^{2001}, b^{98}\right)-f\left(y^{98}\right)\right\}
\end{aligned}
$$

Results are quite similar, with greater room for effects of attitudes above roughly the $70^{\text {th }}$ percentile of the distribution of equity holdings.

Thus, counterfactual analysis suggests that the period 1989-1998 has witnessed a tilt of the stockholder base towards smaller holdings, partly because of financial attitudes and practices. The subsequent, 1998-2001 period is even more interesting, as it seems to combine a shift in the composition of characteristics, attitudes and practices of the stockholder base towards larger holdings despite the continuing increase in overall participation. To put it differently, our findings suggest that the stock market downswing has had a 'cleansing effect' on the characteristics, attitudes, and practices of the stockholder pool. ${ }^{13}$

\section{How important is Stockholding for Net Wealth Inequality?}

In this Section, we document changes in inequality of net total wealth among US households between 1989 and 2001 and investigate the importance of stockholding for these changes. ${ }^{14}$ The first subsection computes net wealth inequality indices to show that different parts of the distribution of net wealth have been affected quite differently over this period, rendering blanket statements about net wealth inequality misleading. The second subsection presents inequality decompositions by asset components to show that, despite the rich pattern of inequality changes, stock investing has become dramatically more important for net wealth

\footnotetext{
${ }^{13}$ As noted above, this was partly accomplished through exits of smaller investors. It may have also been helped by improvements in the financial attitudes and practices of some investors who remained in the market following the downswing.

14 The measurement part of our analysis of wealth distribution is complementary to the careful work by Kennickell (2003), which is based on the same set of SCF surveys. Kopczyk and Saez (2003) use estate tax returns to study shares of wealth held by the very rich and they find, consistent with Kennickell, that top wealth shares have not increased since 1995, and that the share of stock market wealth held by the richest (relative to the total stock market wealth held by the whole population) fell in the past 20 years. They attribute the latter finding partly to increased stock market participation.
} 
inequality regardless of whether we focus mainly on inequality at the upper end or in the middle of the distribution.

\subsection{How has Net Wealth Inequality Changed?}

As discussed, data from SCF are particularly well suited for analysis of the wealth distribution, given that they over sample the rich and they are not subject to top-coding of wealthy households carried out in other surveys. It should be noted that the presence of the rich is very important in studying the wealth distribution and inequality since the richest $1 \%$ of households possesses roughly the 1/3 of the total wealth (see Kennickell, 2003).

We first compute four commonly used measures of inequality, which are sensitive to changes in different parts of the distribution ${ }^{15}$ : Mean logarithmic deviation (MLD), Theil, Half of Squared Coefficient of Variation (HSCV), and Gini. Theil's index is influenced by the relative distance between the rich and the poor, attaching more weight to transfers at the lower and upper ends. HSCV is very sensitive to changes in the upper tail of the distribution: it is very sensitive to inequality at high wealth levels but less so to inequality at other regions of the distribution (Cowell, 1977; Shorrocks, 1980). Gini is more sensitive to the middle of the distribution.

Table 3 reports computed values of four inequality indices for net overall wealth in 1989, 1998, and 2001. ${ }^{16}$ MLD records a sizeable decrease in inequality between 1989 and 1998, followed by an increase to a level in 2001 that falls short of inequality at the starting point. Theil and HSCV record increased inequality in 1998 compared to 1989 , followed by a reduction in inequality between 1998 and 2001. Finally, Gini records a slight increase in net wealth inequality over time.

\footnotetext{
15 As Atkinson (1983) points out, "[inequality indices] embody implicit judgments about the weight to be attached to the inequality at different points in the [...] scale". Details on the asset definitions are available from the authors on request. Formulae for inequality indices are provided in Appendix C.

${ }^{16}$ Inequality indices for gross total wealth over the full sample of households produce a similar picture.
} 
The patterns we observe, especially the movements in HSCV and Theil, suggest that net wealth inequality at the upper end of the wealth distribution increased during the stock market upswing and the spread of defined contribution pension plans of the 1990s and diminished during the subsequent downturn. The increase in the Gini coefficient suggests some increase in inequality among middle net-wealth classes throughout the period under examination.

\subsection{The Growth in Importance of Stockholding for Net Wealth Inequality}

Appropriate decompositions of inequality indices allow us to investigate the relative importance of different asset components of net total wealth for generating inequality at different points in the distribution. Inequality in a variable $W$ in a given year, $I_{W}$, can be expressed as an exact sum of the contributions made by its various factor components:

$$
I_{W}=\sum_{f} S_{f}
$$

A factor component contributes to increased (reduced) inequality if $S_{f}>0(<0)$. The share of

a particular factor $f, s_{f}$, in generating inequality is defined as: $s_{f}=\frac{S_{f}}{I_{W}}$, and thus: $\sum_{f} s_{f}=1$. In what follows, we focus on the top of the net wealth distribution (which accounts for the main bulk of equity holdings) using the HSCV as well as on the middle of the distribution using the Gini. Despite their recorded differences, decompositions of both measures point to the substantial growth in importance of stockholding for net wealth inequality.

\subsubsection{Decomposition of HSCV by Source}

HSCV has desirable decomposability properties and it can handle the regular 
incidence of zero asset holdings. ${ }^{17}$ Appendix C provides details on the exact decomposition of HSCV into the factor components reported in Table 4.

Table 4 shows decompositions of inequality by source, as measured by HSCV. ${ }^{18}$ Stock holdings are not the dominant source of net wealth inequality, but neither is primary residence that forms the biggest part of most households' portfolio. Indeed, wealth in primary residence has a much smaller effect on net wealth inequality than stockholding, and one not consistent with the overall trend.

The factor with the greatest proportional contribution to net wealth inequality is risky real assets (business equity and investment real estate excluding primary residence), which make a more than 50 percent contribution in all three years $(1989,1998,2001)$. Yet ownership rates of risky real assets do not exhibit any strong trend between 1989 and 2001, hovering around 27 percent. Risky real assets exhibit high degree of inequality and high correlation with overall net wealth, but in 1998 , the year that overall inequality spikes by the HSCV measure, the absolute factor contribution of risky real assets and business equity increases only slightly (from 10.16 to 11.63 ). ${ }^{19}$ Given the much higher increase in net total wealth inequality, the proportionate factor contribution actually drops (from 0.72 to 0.60 ).

Stock holdings, on the other hand, represent the factor with the biggest growth in importance and they exhibit changes in inequality consistent with those of net wealth. By 1998, wealth in equity holdings accounts for more than 25 percent of net total wealth inequality, compared to just 7 percent a decade before. ${ }^{20}$ Directly and indirectly held equity plays the dominant role in the increase of overall net wealth inequality by 1998 , based on the

\footnotetext{
${ }^{17}$ See Jenkins (1995) for a similar argument in favor of using HSCV for analysis of income inequality.

${ }^{18}$ Decompositions presented in tables 2 and 3 have been also applied to gross total wealth using the full sample of households and excluding the two categories that represent debt. In all cases they suggest similar patterns to those we present.

19 This is because the dropping factor share and correlation with net total wealth moderate the effects from the increase in this factor's inequality.

${ }^{20}$ Stock holdings exhibit a high increase in factor share, increased correlation with net total wealth, and increased inequality (coming from the increase in within inequality that almost doubles, outweighing the effect
} 
percentage change in source contributions. Between 1998 and 2001, reduction in inequality of equity holdings (attributable mainly to the significant reduction in inequality among equity holders but also to the higher percentage of owners) more than outweighs the increase in their relative correlation and share, contributing to a fall in net total wealth inequality. However, their proportionate contribution to net wealth inequality remains at $25 \%$. One may wonder whether these conclusions on the importance of stockholding depend on using HSCV, which is sensitive to the upper tail of the distribution. The next subsection examines robustness with respect to using the Gini index.

\subsubsection{Decomposition of the Gini Index by Source}

Despite the fact that the Gini coefficient focuses on the middle of the distribution and records increased inequality throughout the period under study, Gini decompositions reinforce the conclusions based on HSCV.

Table 5 reports decompositions of inequality of net total wealth as summarized by the Gini coefficient (see Appendix $\mathrm{C}$ for explanation of the exact decomposition). Equity holdings display one of the highest rank correlation ratios, which gets higher over time, highlighting the growing importance of risky financial assets for households' position in the overall net wealth distribution. In the period 1989-98, only stock holdings exhibit an increase in absolute and proportionate contributions to net wealth inequality. The main factor behind this increased contribution is the rise in its share of net total wealth over this period, mainly due to the spread of participation to more households and the increases in valuation during the upswing.

All in all, we do not find that either stock wealth or net overall wealth inequality fell consistently through the period of sustained increase in stock market participation. Net wealth

from the increase in the percentage of stock owners), all leading to a more than quadruple increase in their 
inequality has followed the same pattern as stock wealth inequality over the period and stock wealth inequality has grown in importance significantly as a component of net wealth inequality.

\section{Concluding Remarks}

Household participation in stockholding grew dramatically in the US in the face of the stock market upswing and spread of defined contribution pension plans during the 1990s, and of the subsequent downswing in the early 2000s. In this paper, we have employed highquality household-level data from the SCF to shed light on the important links between increased participation in stockholding, changing characteristics of the stockholding pool, and net wealth inequality.

We used counterfactual decomposition techniques in order to attribute changes in stock investing in two points in time into a part that is due to changes in the economic environment and another part that is due to changes in the configuration of characteristics of the stockholder pool. Our results imply that the share of smaller stockholders was raised during the booming stock market of the 1990s, while the subsequent downturn improved the tendency of the stockholder pool to exhibit large equity holdings. In this sense, the US experience between 1989 and 2001 seems consistent with a 'dilution effect' during the stock market boom, followed by a 'cleansing effect' of the stock market downturn. Our findings support the view that heterogeneity in household characteristics, as well as financial attitudes and practices, matter for stockholding levels.

We found inequality in equity holdings to be quite important for inequality in overall net wealth, despite their limited share in net wealth. However, our findings suggest that reduced wealth inequality is far from being an automatic outcome of the spread of stock

absolute factor contribution between 1989 and 1998. 
market participation. The distributions of stock holding and net wealth levels are significantly influenced both by household characteristics and by their financial attitudes and practices. By highlighting the importance of such factors for net wealth inequality, our findings contribute to the debate on the importance of financial education, advice, and well-designed default options, as responsibility for retirement financing is shifted from Social Security to households, challenging disproportionately the small and less sophisticated investors. 


\section{References}

Albrecht, James, Anders Björklund, and Susan Vroman (2003). "Is There a Glass Ceiling in Sweden?", Journal of Labor Economics, 21, 145-77.

Allen, Franklin and Douglas Gale (1994). "Limited Market Participation and Volatility of Assets Prices", The American Economic Review, 84, 933-55.

Arrow, Kenneth (1987). "The Demand for Information and the Distribution of Income", Probability in the Engineering and the Informational Sciences 1, 3-13.

Atkinson, Anthony (1983). The Economics of Inequality, Clarendon Press, Oxford.

Autor, David H., Lawrence F. Katz, and Melissa S. Kearney (2008). "Trends in U.S. Wage Inequality: Revising the Revisionists", The Review of Economics and Statistics, 90(2), $300-23$.

Barberis, Nicholas and Richard Thaler (2003). 'A Survey of Behavioral Finance' in G.M. Constantinides, M. Harris and R. Stulz (Eds.), Handbook of the Economics of Finance, Elsevier Science B.V.

Bertaut, Carol C. and Martha Starr-McCluer (2002). "Household Portfolios in the United States", in L. Guiso, M. Haliassos, and T. Jappelli (Eds.), Household Portfolios, Cambridge, MA: MIT Press.

Bilias, Yannis, Dimitris Georgarakos, and Michael Haliassos (2010). "Portfolio Inertia and Stock Market Fluctuations.” Journal of Money, Credit, and Banking, 42:4, 715-742.

Calvet, Laurent, John Y. Campbell, and Paolo Sodini (2007). "Down or Out: Assessing the Welfare Costs of Household Investment Mistakes", Journal of Political Economy, 115, 707-47.

Campbell, JohnY. (2006). "Household Finance”, Journal of Finance, 61, 1553-604.

Campbell, John Y. and Luis Viceira (2002). Strategic Asset Allocation: Portfolio Choice for Long-term Investors, Oxford: Oxford University Press.

Carroll, Christopher D. (2001). "Portfolios of the Rich" in L. Guiso et al. (Eds.), Household Portfolios, Cambridge, MA: MIT Press.

Christelis, Dimitris, Dimitris Georgarakos, and Michael Haliassos (2011). "Stockholding: Participation, location, and spillovers." Journal of Banking and Finance, 35:8, 19181930.

Christelis, Dimitris, Dimitris Georgarakos, and Michael Haliassos (2013). "Differences in Portfolios Across Countries: Economic Environment versus Household Characteristics." Review of Economics and Statistics, 95:1, 220-236.

Cocco, J., F. Gomes, and P.J. Maenhout (2005). "Consumption and Portfolio Choice over the Life Cycle," Review of Financial Studies, 18:2, 491-533. 
Cowell, Frank (1977). Measuring Inequality, Philip Allan, Oxford.

Gollier, Christian (2001). The Economics of Risk and Time, Cambridge, MA: MIT Press.

Gomes, Francisco and Alexander Michaelides (2004). "Optimal Life-Cycle Allocation: Understanding the Empirical Evidence", Journal of Finance, 60(2), 869-904.

Graham, J.R., C.R. Harvey, H. Huang (2009). "Investor Competence, Trading Frequency, and Home Bias". Management Science, 55, 1094-106.

Greene William (2000). Econometric Analysis, New York: Macmillan.

Guiso, Luigi, Michael Haliassos, and Tullio Jappelli (2003). "Household Stockholding in Europe: Where Do We Stand, Where Do We Go?", Economic Policy, April 2003, 117 164.

Guiso, Luigi, Michael Haliassos, and Tullio Jappelli (Eds.) (2001). Household Portfolios, Cambridge, MA: MIT Press.

Guvenen, Fatih (2006), "Reconciling Conflicting Evidence on the Elasticity of Intertemporal Substitution: a Macroeconomic Perspective", Journal of Monetary Economics, 53(7), 1451-1472.

Haliassos, Michael and Carol C. Bertaut (1995)."Why Do So Few Hold Stocks?" The Economic Journal, 105, 1110-29.

Haliassos, Michael and Alexander Michaelides (2003). "Portfolio Choice and Liquidity Constraints", International Economic Review, 44, 143-78.

Heaton, John and Deborah Lucas (1999). "Stock Prices and Fundamentals", NBER Macroeconomics Annual, 213-42.

Heaton, John and Deborah Lucas (2000). "Portfolio Choice in the Presence of Background Risk", The Economic Journal, 110, 1-26.

Herrera, Helios (2001). "Participation Externalities and Stock Market Volatility", mimeo, New York University.

Hurst, Erik and Anna Maria Lusardi (2004). "Liquidity Constraints, Household Wealth and Entrepreneurship", Journal of Political Economy, 112, 319-47.

Investment Company Institute and the Securities Industry Association (2005), Equity Ownership in America, 2005.

Jenkins, Stephen (1995). “Accounting for inequality trends: decomposition analysis for the UK, 1971-1986”, Economica, 62, 29-63.

Kennickell, Arthur (2003). "A Rolling Tide: Changes in Changes in the Distribution of Wealth in the U.S., 1989-2001", mimeo. 
King Gary, Michael Tomz, and Jason Wittenberg (2003). "Clarify: Software for Interpreting and Presenting Statistical Results", Journal of Statistical Software, 8, no. 1.

Kopczuk, Wojciech and Emmanuel Saez (2004). "Top Wealth Shares in the United States, 1916-2000: Evidence from Estate Tax Returns", National Tax Journal, 57, 445-87.

Lerman, Robert and Shlomo Yitzhaki (1985). "Income inequality effects by income source: A new approach and applications to the United States", Review of Economics and Statistics, 67, 151-56.

Lusardi, Annamaria and Olivia S. Mitchell (2007). "Baby Boomer Retirement Security: The roles of planning, financial literacy, and housing wealth", Journal of Monetary Economics, 54, 205-24.

Mata, José and José Machado (2005). "Counterfactual Decomposition of Changes in Wage Distributions Using Quantile Regression", Journal of Applied Econometrics, 20(4), 445-65.

Nguyen, Binh, James Albrecht, Susan Vroman, and M.Daniel Westbrook (2007). "A Quantile Regression Decomposition of Urban-Rural Inequality in Vietnam", Journal of Development Economics, 83(2), 466-490.

Oaxaca, R. (1973). "Male-Female Wage Differentials in Urban Labor Markets", International Economic Review, 14, 693-709.

Pagano, Marco (1989). "Endogenous Market Thinness and Stock Price Volatility", The Review of Economic Studies, 56, 269-87.

Peress, Joel (2004). "Wealth, Information Acquisition, and Portfolio Shares," Review of Financial Studies, 17(3), 879-914.

Rubin, Donald (1987). Multiple Imputation for Nonresponse in Surveys. New York: John Wiley \& Sons.

Shorrocks, Anthony (1980). “A Class of Decomposable Inequality Measures”, Econometrica, $48,613-625$.

Shorrocks, Anthony (1982). "Inequality Decomposition by Factor Components", Econometrica, 50, 193-212.

Wolff, Edward (1998). "Recent Trends in the Size Distribution of Household Wealth", The Journal of Economic Perspectives, 12, 131-150.

Van Rooij, Maarten, Annamaria Lusardi, and Rob Alessie (2011). "Financial Literacy and Stock Market Participation”, Journal of Financial Economics, 101(2), pp. 449-472.

Van Rooij, Maarten, Annamaria Lusardi, and Rob Alessie (2012). "Financial Literacy, Retirement Planning and Household Wealth.” Economic Journal, 122(560), 449-478. 


\section{Appendix A: Simulated Average Marginal Effects}

Standard econometric packages automatically report marginal effects for each variable evaluated at mean remaining characteristics. Although it is standard practice to report such automatically generated marginal effects, this is often not economically relevant and sometimes even misleading. For example, it fails to distinguish among single dummy variables and groups of dummy variables that represent a given attribute; or properly evaluate effects of continuous variables entering with particular nonlinear forms. ${ }^{21}$. Deriving averages of marginal effects that have been first evaluated at each single observation can provide instead a more realistic and economically relevant interpretation.

In this paper, we compute reported marginal effects in the following way. We start by estimating the relevant limited dependent variable model. We then simulate the model parameters (including $\rho$ for probit models with selection) by making 1000 independent draws from the multivariate normal distribution, subject to the restrictions that the average of simulated values be equal to the respective estimated parameter and that the structure of the estimated robust variance covariance matrix be preserved. For each such set of simulated parameters, we calculate marginal effects for each individual household and then derive the weighted average marginal effect for the relevant population. We repeat the process for every set of simulated parameters, thus computing a series of average marginal effects. The mean of this series is the estimated marginal effect and the standard error is the simulated standard error of the marginal effect.

In the cases of probit model with selection we compute conditional marginal effects, using the formulae described in Greene (2000, p.857 \& 860) and calculating the average marginal effects over the selected sample.

Finally it should be noted that SCF data have been constructed on the basis of repeated imputation, to eliminate missing values. Five different sets of imputed data are provided. We take into account this feature, by first applying the above procedure to each of the five implicates and then deriving marginal effects and standard errors that are corrected for multiple imputation according to Rubin (1987).

\section{Appendix B: The Machado-Mata Algorithm}

The algorithm for constructing counterfactual distributions is a variant of Machado and Mata (2005), recently used by Albrecht, Björklund and Vroman (2003) and Nguyen et al. (2007):

1. Draw $m$ random numbers from a uniform distribution on $(0,1): \theta_{1}, \theta_{2}, \ldots \ldots \theta_{m} ;$ here we set $m=2000$.

2. For each $\theta_{i}$ where $\mathrm{i}=1,2, \ldots, m$, use the 1998 data on stockholders to estimate the Quantile Regression coefficient, $b^{98}\left(\theta_{i}\right)$, from the model:

$$
Q_{\theta_{i}}^{98}\left[y \mid X^{98}\right]=X^{98} \beta^{98}\left(\theta_{i}\right)
$$

\footnotetext{
${ }^{21}$ There is growing discussion of these issues and an effort to provide codes that circumvent some inefficiencies of standard software packages (see, for instance, King, Tomz and Wittenberg, 2003).
} 
3. Make $m$ random draws of characteristics and corresponding weights with replacement from the 1989 stockholder pool. Denote the outcomes of these draws by $x_{i}^{* 89}$ for $\mathrm{i}=$ $1,2, \ldots, m$.

4. Generate counterfactual values (a random sample of size $m$ from the desired distribution): $\quad y_{i}^{*}=x_{i}^{* 89} b^{98}\left(\theta_{i}\right)$, for $\mathrm{i}=1,2, \ldots, m$. Use these values to generate $f^{*}\left(y ; X^{89} b^{98}\right)$.

Then, for each of the three sequences of variables (log equity holdings in 1989 and 1998 and counterfactual values), we calculate percentiles using population weights. The difference between percentiles of the distributions of the endogenous variable in 1998 and 1989 can be decomposed into:

$$
f\left(y^{98}\right)-f\left(y^{89}\right)=\left\{f\left(y^{98}\right)-f^{*}\left(y ; X^{89} b^{98}\right)\right\}+\left\{f^{*}\left(y ; X^{89} b^{98}\right)-f\left(y^{89}\right)\right\}
$$

The term in the first curly brackets represents the contribution of the covariates to the overall difference between the 1998 and 1989 distributions, evaluated at each percentile. The term in the second curly brackets shows the contribution of the QR coefficients. The method is a generalization of Oaxaca (1973) to the whole distribution.

We further decompose the covariate effects into the contribution made by household characteristics that can be seen as fundamentals and a remaining contribution that is due to particular attitudes and practices. We assess the contribution of three attitudes, namely financial alertness, willingness to take more than average risk, and expect to leave a bequest. To this end we use the following sequential decomposition:

$$
\begin{aligned}
f\left(y^{98}\right)-f\left(y^{89}\right) & =\left\{f\left(y^{98}\right)-f^{* *}\left(y ; X_{f}^{98}, X_{a}^{89}, b^{98}\right)\right\} \\
& +\left\{f^{* *}\left(y ; X_{f}^{98}, X_{a}^{89}, b^{98}\right)-f^{*}\left(y ; X^{89} b^{98}\right)\right\} \\
& +\left\{f^{*}\left(y ; X^{89} b^{98}\right)-f\left(y^{89}\right)\right\}
\end{aligned}
$$

where the counterfactual $f^{* *}$ represents the equity wealth distribution that would have prevailed in 1998 if the particular attitudes had been distributed as in 1989. The term in the first curly bracket shows the relative contribution of attitudes, while in the second the relative contribution of fundamentals.

In order to construct the counterfactual $f^{* *}$ we first divide each of the samples of equity owners in 1989 and 1998 into 8 cells representing all the possible combinations of the three attitudes. We follow steps 1 and 2 from above while in step 3 we make $m$ random draws with replacement from 1998 sample, generating the 1998 equity wealth distribution implied by the model. Then we consider the subset of households in cell 1 . We randomly draw with replacement observations from this subset to generate a relative sample size equal to the fraction of households in cell 1 in 1989. We repeat the last two steps for cells 2 to 8 . A similar approach is followed for the period 1998-2001. 


\section{Appendix C: Formulae for inequality indices and their decompositions}

Mean logarithmic deviation (MLD) of variable $y$ with mean $\mu$ and $n$ observations is defined as:

$$
M L D \equiv G E(0)=\frac{1}{n} \sum_{i=1}^{n} \log \frac{\mu}{y_{i}}
$$

The Theil index is given by

$$
\text { Theil } \equiv G E(1)=\frac{1}{n} \sum_{i=1}^{n} \frac{y_{i}}{\mu} \log \frac{y_{i}}{\mu}
$$

Half of the square of the coefficient of variation (HSCV) is given by

$$
H S C V \equiv G E(2)=\frac{1}{2 n \mu^{2}} \sum_{i=1}^{n}\left(y_{i}-\mu\right) y_{i}=\frac{\operatorname{var}(y)}{2 \mu^{2}}
$$

It can be shown that the more positive $a$ is, the more sensitive $\operatorname{GE}(a)$ is to inequality at the top of the distribution.

The Gini coefficient is of the form:

$$
\text { Gini }=\frac{2}{n^{2} \mu} \sum_{i=1}^{n}\left(i-\frac{n+1}{2}\right) y_{i}
$$

where $y_{i}^{\prime}$ s are in ascending order.

Decomposition of HSCV

Shorrocks (1982) proved that, under certain axioms, there is a unique 'decomposition rule', according to which the proportionate contribution of factor $f$ can be derived - for a broad set of inequality measures - from:

$$
s_{f}=\frac{\operatorname{cov}(f, W)}{\sigma_{W}^{2}}
$$

This is actually equivalent to the OLS estimated slope coefficient from the regression of wealth factor $f$ on net total wealth $W$.

When inequality is summarized by HSCV,

$$
s_{f}=\rho_{f W} \chi_{f} \sqrt{\frac{I_{f}}{I_{W}}}
$$

This expresses the proportionate contribution of factor $f$ in terms of factor correlation with total net wealth $\rho_{f W}$, the factor's share in net total wealth $\chi_{f}$, net total wealth inequality $I_{W}$ and the factor inequality $I_{f}$, both measured by the HSCV. Thus, the absolute contribution of factor $f$ is: $S_{f}=\rho_{f W} \chi_{f} \sqrt{I_{W} I_{f}}$.

The percentage of factor owners $n_{f}^{+}$and the inequality they exhibit among them $I_{f}^{+}$ have a - disproportionate and proportionate, respectively - effect on the factor contribution to 
inequality, given in approximation by: $I_{f}=\left(\frac{1}{n_{f}^{+}}\right)\left(I_{f}^{+}+1\right)-1$ (Jenkins, 1995). Hence, in our tables presenting wealth decompositions, we report along with factor correlations, factor shares, and factor inequalities, percentages of factor owners, and within factor inequalities.

Finally, we also compute a measure of each factor's contribution to the evolution of inequality over time. A factor making an important contribution to total inequality in a given year does not necessarily play a prominent role in inequality changes over time. Following Jenkins (1995) we decompose HSCV trends over time as: $\% \Delta I=\frac{I_{t+1}-I_{t}}{I_{t}}=\sum_{f} s_{f} \% \Delta S_{f}$, where a large positive value of $s_{f} \% \Delta S_{f}$ suggests an important role for factor $f$ in raising total inequality over time.

\section{Decomposition of Gini}

The commonly used Lerman and Yitzhaki (1985) decomposition of the Gini index expresses the absolute contribution of wealth factor $f$ to overall inequality as:

$$
S_{f}=G_{f} \chi_{f} R_{f W}
$$

where $G_{f}$ is the inequality of factor $f$ measured by Gini, $\chi_{f}$ is the share of factor $f$ in net total wealth, and $R_{f W}$ is the "rank correlation ratio" defined as the ratio of the covariance of household's amount of wealth factor $f$ with its ranking in the cumulative distribution of net total wealth, over the covariance of its amount of wealth factor $f$ with its ranking in the cumulative distribution of factor $f$. 
Table 1: Probit Regressions for Ownership of Equity Holdings

\begin{tabular}{|c|c|c|c|c|c|c|}
\hline & \multicolumn{2}{|l|}{1989} & \multicolumn{2}{|l|}{1998} & \multicolumn{2}{|l|}{2001} \\
\hline & $\begin{array}{l}\text { Marginal } \\
\text { Effect }\end{array}$ & $\begin{array}{c}t- \\
\text { value }\end{array}$ & $\begin{array}{l}\text { Marginal } \\
\text { Effect }\end{array}$ & $\begin{array}{c}t- \\
\text { value }\end{array}$ & $\begin{array}{l}\text { Marginal } \\
\text { Effect }\end{array}$ & $\begin{array}{c}t- \\
\text { value }\end{array}$ \\
\hline Age & $0.0031 * * *$ & 4.62 & $0.0027 * * *$ & 4.60 & 0.0006 & 0.91 \\
\hline Male & 0.0097 & 0.33 & 0.0041 & 0.17 & 0.0346 & 1.41 \\
\hline Married & $0.0720 * * *$ & 2.81 & $0.0985 * * *$ & 4.25 & $0.0645 * * *$ & 3.15 \\
\hline Has children & $-0.0395 * *$ & -2.23 & $-0.0255 *$ & -1.69 & -0.0086 & -0.57 \\
\hline White & $0.1244 * * *$ & 5.89 & $0.1412 * * *$ & 7.73 & $0.1166 * * *$ & 6.47 \\
\hline Health poor & $-0.1287 * * *$ & -4.06 & $-0.0796 * *$ & -2.25 & $-0.1849 * * *$ & -5.55 \\
\hline High school graduate & $0.1556 * * *$ & 6.86 & $0.1918 * * *$ & 8.03 & $0.1969 * * *$ & 8.25 \\
\hline College graduate & $0.2867 * * *$ & 11.27 & $0.3437 * * *$ & 13.11 & $0.3638 * * *$ & 14.05 \\
\hline Save for "rainy days" & -0.0050 & -0.32 & -0.0026 & -0.18 & -0.0049 & -0.32 \\
\hline Credit constrained & $-0.0407 *$ & -1.68 & -0.0086 & -0.49 & $-0.0476 * *$ & -2.44 \\
\hline Non-investment Income & $0.0076 * * *$ & 5.99 & $0.0086 * * *$ & 6.92 & $0.0071 * * *$ & 7.00 \\
\hline $\begin{array}{l}\text { Non-equity net total } \\
\text { Wealth }\end{array}$ & $0.0116 * * *$ & 7.11 & $0.0088 * * *$ & 7.54 & $0.0087 * * *$ & 7.68 \\
\hline Expect to leave a bequest & $0.0784 * * *$ & 4.65 & $0.1144 * * *$ & 7.84 & $0.1128 * * *$ & 7.98 \\
\hline Has received inheritance & $0.0292 *$ & 1.77 & $0.0697 * * *$ & 4.17 & $0.0489 * * *$ & 2.64 \\
\hline Financial alertness & -0.0197 & -1.20 & 0.0239 & 1.21 & 0.0177 & 1.06 \\
\hline $\begin{array}{l}\text { Willingness to take above } \\
\text { average financial risk }\end{array}$ & $0.0809 * * *$ & 3.89 & $0.1871 * * *$ & 11.75 & $0.1701 * * *$ & 10.34 \\
\hline Investment horizon $>10 \mathrm{yrs}$ & $0.0481 * *$ & 2.44 & $0.1076 * * *$ & 4.96 & $0.0486 * * *$ & 2.65 \\
\hline observations & \multicolumn{2}{|l|}{3,143} & \multicolumn{2}{|l|}{4,305} & \multicolumn{2}{|l|}{4,442} \\
\hline log likelihood & -1530.8 & & -1982.8 & & -1970.2 & \\
\hline
\end{tabular}

Data from Surveys of Consumer Finances. The specification accounts for age through a $2^{\text {nd }}$ order polynomial, and for labor status. It controls for income, and non equity net total wealth using the inverse hyperbolic sine transformation: $\log \left(\mathrm{x}+\left(\mathrm{x}^{2}+1\right)^{1 / 2}\right)$. Marginal effects are averaged across households (using survey weights). The marginal effects for income and non equity net total wealth are based on a $\$ 5000$ increase in the underlying variables and for age on a one year increase. Numbers in italics report t-values, derived from simulated standard errors (details can be found in appendix A). ****** and * denote significance at $1 \%, 5 \%$ and $10 \%$ level, respectively. Reported estimates are corrected for multiple imputation. 
Table 2: Educational Attainment, Income and net Wealth in the Population and among Equity Owners

\begin{tabular}{|c|c|c|c|}
\hline & 1989 & 1998 & 2001 \\
\hline \multicolumn{4}{|l|}{ Population } \\
\hline \multicolumn{4}{|l|}{ Education $(\%)$} \\
\hline Less than high school education & 23.3 & 15.4 & 15.2 \\
\hline High school graduates & 48.8 & 51.4 & 50.9 \\
\hline College degree or more & 27.9 & 33.2 & 33.9 \\
\hline Mean (Median) non-investment Income & $\begin{array}{r}51,203 \\
(35,168)\end{array}$ & $\begin{array}{r}56,538 \\
(37,245)\end{array}$ & $\begin{array}{r}64,102 \\
(38,691)\end{array}$ \\
\hline Mean (Median) non-equity Net total Wealth & $\begin{array}{r}249,749 \\
(66,469)\end{array}$ & $\begin{array}{l}244,506 \\
(68,579)\end{array}$ & $\begin{array}{c}308,318 \\
(76,679)\end{array}$ \\
\hline Equity Owners (\%) & 31.8 & 48.9 & 51.9 \\
\hline \multicolumn{4}{|l|}{ Equity Owners } \\
\hline Education $(\%)$ & & & \\
\hline Less than high school education & 7.3 & 5.4 & 4.7 \\
\hline High school graduates & 45.5 & 47.8 & 45.7 \\
\hline College degree or more & 47.2 & 46.8 & 49.6 \\
\hline Mean (Median) non-investment Income & $\begin{array}{r}87,145 \\
(61,161) \\
\end{array}$ & $\begin{array}{r}82,825 \\
(58,783) \\
\end{array}$ & $\begin{array}{r}93,731 \\
(61,091)\end{array}$ \\
\hline Mean (Median) non-equity net total Wealth & $\begin{array}{r}513,993 \\
(181,918) \\
\end{array}$ & $\begin{array}{r}390,595 \\
(127,400) \\
\end{array}$ & $\begin{array}{r}486,494 \\
(154,720) \\
\end{array}$ \\
\hline
\end{tabular}

Weighted data from Surveys of Consumer Finances. The reported statistics are corrected for multiple imputation. The sample of equity owners includes households who own directly or indirectly stocks. Money values refer to 2004 Dollars. 
Table 3: Net Wealth Inequality Indices

\begin{tabular}{c|c|c|c|c}
\hline \hline & \multicolumn{3}{|c|}{ Generalized Entropy Class } & \\
\hline Year & GE(0) & GE(1) & GE(2) & Gini \\
& MLD & Theil & HSCV & \\
\hline 1989 & 2.022 & 1.523 & 14.037 & 0.769 \\
\hline 1998 & 1.860 & 1.646 & 19.156 & 0.776 \\
\hline 2001 & 1.966 & 1.622 & 12.847 & 0.788 \\
\hline \hline
\end{tabular}

Weighted data from Surveys of Consumer Finances. The reported statistics are corrected for multiple imputation. The sample excludes households with negative net worth. 
Table 4: Net Wealth Inequality Decomposition by Sources using HSCV

\begin{tabular}{|c|c|c|c|c|c|c|c|c|c|}
\hline & Year & $\begin{array}{l}\text { Net } \\
\text { Total } \\
\text { Wealth }\end{array}$ & $\begin{array}{l}\text { Wealth in } \\
\text { Safe } \\
\text { Financial } \\
\text { Assets }\end{array}$ & $\begin{array}{l}\text { Wealth in } \\
\text { Equity } \\
\text { Holdings }\end{array}$ & $\begin{array}{l}\text { Net Wealth in } \\
\text { Risky Real } \\
\text { Assets \& } \\
\text { Bus. Equity }\end{array}$ & $\begin{array}{l}\text { Other } \\
\text { Wealth }\end{array}$ & $\begin{array}{l}\text { Wealth in } \\
\text { Primary } \\
\text { Residence }\end{array}$ & $\begin{array}{l}\text { Principal } \\
\text { Residence } \\
\text { Debt }\end{array}$ & $\begin{array}{l}\text { Consumer } \\
\text { Debts }\end{array}$ \\
\hline Percentage & 1989 & 0.957 & 0.907 & 0.339 & 0.289 & 0.857 & 0.681 & 0.418 & 0.615 \\
\hline with positive & 1998 & 0.973 & 0.936 & 0.512 & 0.271 & 0.850 & 0.703 & 0.454 & 0.607 \\
\hline $\begin{array}{l}\text { factor wealth } \\
\left(\mathbf{n}_{f}^{+}\right)\end{array}$ & 2001 & 0.971 & 0.937 & 0.537 & 0.259 & 0.870 & 0.714 & 0.468 & 0.616 \\
\hline Factor & 1989 & 1.000 & 0.251 & 0.100 & 0.353 & 0.061 & 0.356 & -0.093 & -0.029 \\
\hline Share & 1998 & 1.000 & 0.219 & 0.254 & 0.296 & 0.054 & 0.320 & -0.115 & -0.029 \\
\hline$\left(\chi_{f}\right)$ & 2001 & 1.000 & 0.212 & 0.268 & 0.287 & 0.048 & 0.307 & -0.102 & -0.022 \\
\hline Correlation & 1989 & 1.000 & 0.542 & 0.446 & 0.905 & 0.267 & 0.401 & -0.174 & -0.264 \\
\hline with net & 1998 & 1.000 & 0.559 & 0.647 & 0.863 & 0.358 & 0.401 & -0.160 & -0.358 \\
\hline $\begin{array}{l}\text { total wealth } \\
\left(\rho_{f W}\right)\end{array}$ & 2001 & 1.000 & 0.639 & 0.682 & 0.825 & 0.370 & 0.507 & -0.183 & -0.203 \\
\hline Factor & 1989 & 14.037 & 16.831 & 37.110 & 72.197 & 31.696 & 1.362 & 2.351 & 11.891 \\
\hline Inequalities & 1998 & 19.156 & 14.592 & 46.750 & 108.032 & 7.909 & 1.376 & 1.696 & 26.424 \\
\hline$\left(\mathbf{I}_{f}\right)$ & 2001 & 12.847 & 18.211 & 24.825 & 63.960 & 8.038 & 1.561 & 1.836 & 22.817 \\
\hline Within Factor & 1989 & 13.409 & 15.226 & 12.257 & 20.257 & 27.318 & 0.767 & 0.692 & 7.126 \\
\hline Inequality & 1998 & 18.628 & 13.631 & 23.695 & 28.881 & 6.649 & 0.819 & 0.498 & 15.851 \\
\hline$\left(\mathbf{I}_{f}^{+}\right)$ & 2001 & 12.462 & 17.036 & 13.106 & 16.178 & 6.932 & 0.971 & 0.592 & 13.857 \\
\hline Proportionate & 1989 & 1.000 & 0.149 & 0.073 & 0.722 & 0.025 & 0.045 & -0.007 & -0.007 \\
\hline Factors & 1998 & 1.000 & 0.107 & 0.258 & 0.606 & 0.012 & 0.034 & -0.005 & -0.012 \\
\hline $\begin{array}{l}\text { contributions } \\
\left(\mathbf{s}_{f}\right)\end{array}$ & 2001 & 1.000 & 0.162 & 0.254 & 0.529 & 0.014 & 0.054 & -0.007 & -0.006 \\
\hline Absolute & 1989 & 14.037 & 2.082 & 1.013 & 10.163 & 0.346 & 0.622 & -0.093 & -0.098 \\
\hline Factors & 1998 & 19.156 & 2.045 & 4.918 & 11.634 & 0.237 & 0.657 & -0.104 & -0.230 \\
\hline $\begin{array}{l}\text { contributions } \\
\left(\mathbf{S}_{f}\right)\end{array}$ & 2001 & 12.847 & 2.074 & 3.262 & 6.797 & 0.182 & 0.698 & -0.090 & -0.076 \\
\hline $\begin{array}{l}\text { Percentage } \\
\text { change in } \\
\text { source }\end{array}$ & $\begin{array}{l}1998- \\
1989\end{array}$ & 0.365 & -0.003 & 0.280 & 0.105 & -0.008 & 0.003 & -0.001 & -0.009 \\
\hline $\begin{array}{l}\text { contributions } \\
\left(\mathbf{S}_{f} \% \Delta \mathbf{S}_{f}\right)\end{array}$ & $\begin{array}{l}2001- \\
1998\end{array}$ & -0.318 & 0.002 & -0.087 & -0.252 & -0.003 & 0.002 & 0.001 & 0.008 \\
\hline
\end{tabular}

Weighted data from Surveys of Consumer Finances. The reported statistics are corrected for multiple imputation. The sample excludes households with negative net worth. 
Table 5: Net Wealth Inequality Decomposition by Sources using Gini

\begin{tabular}{|c|c|c|c|c|c|c|c|c|c|}
\hline & Year & $\begin{array}{l}\text { Net } \\
\text { Total } \\
\text { Wealth }\end{array}$ & $\begin{array}{l}\text { Wealth in } \\
\text { Safe } \\
\text { Financial } \\
\text { Assets }\end{array}$ & $\begin{array}{l}\text { Wealth in } \\
\text { Equity } \\
\text { Holdings }\end{array}$ & $\begin{array}{l}\text { Net Wealth in } \\
\text { Risky Real } \\
\text { Assets \& } \\
\text { Bus. Equity }\end{array}$ & $\begin{array}{l}\text { Other } \\
\text { Wealth }\end{array}$ & $\begin{array}{l}\text { Wealth in } \\
\text { Primary } \\
\text { Residence }\end{array}$ & $\begin{array}{l}\text { Principal } \\
\text { Residence } \\
\text { Debt }\end{array}$ & $\begin{array}{l}\text { Consumer } \\
\text { Debts }\end{array}$ \\
\hline Factor & 1989 & 1.000 & 0.251 & 0.100 & 0.353 & 0.061 & 0.356 & -0.093 & -0.029 \\
\hline Share & 1998 & 1.000 & 0.219 & 0.254 & 0.296 & 0.054 & 0.320 & -0.115 & -0.029 \\
\hline$\left(\chi_{f}\right)$ & 2001 & 1.000 & 0.212 & 0.268 & 0.287 & 0.048 & 0.307 & -0.102 & -0.022 \\
\hline \multirow{3}{*}{$\begin{array}{l}\text { Rank } \\
\text { correlation } \\
\text { ratio } \\
\left(\mathbf{R}_{f W}\right)\end{array}$} & 1989 & 1.000 & 0.913 & 0.909 & 0.942 & 0.729 & 0.821 & 0.445 & 0.385 \\
\hline & 1998 & 1.000 & 0.902 & 0.932 & 0.945 & 0.654 & 0.812 & 0.443 & 0.329 \\
\hline & 2001 & 1.000 & 0.914 & 0.939 & 0.948 & 0.692 & 0.841 & 0.473 & 0.299 \\
\hline \multirow{3}{*}{$\begin{array}{l}\text { Gini Index } \\
\left(G_{f}\right)\end{array}$} & 1989 & 0.769 & 0.823 & 0.939 & 0.957 & 0.664 & 0.645 & 0.795 & 0.784 \\
\hline & 1998 & 0.776 & 0.809 & 0.908 & 0.955 & 0.618 & 0.605 & 0.749 & 0.794 \\
\hline & 2001 & 0.788 & 0.831 & 0.898 & 0.955 & 0.601 & 0.624 & 0.750 & 0.776 \\
\hline Proportionate & 1989 & 1.000 & 0.245 & 0.111 & 0.414 & 0.039 & 0.245 & -0.043 & -0.011 \\
\hline Factors & 1998 & 1.000 & 0.206 & 0.277 & 0.345 & 0.028 & 0.202 & -0.049 & -0.010 \\
\hline $\begin{array}{l}\text { contributions } \\
\left(\mathbf{s}_{f}\right)\end{array}$ & 2001 & 1.000 & 0.205 & 0.287 & 0.330 & 0.026 & 0.205 & -0.046 & -0.006 \\
\hline Absolute & 1989 & 0.769 & 0.189 & 0.085 & 0.318 & 0.030 & 0.189 & -0.033 & -0.009 \\
\hline Factors & 1998 & 0.776 & 0.160 & 0.215 & 0.267 & 0.022 & 0.157 & -0.038 & -0.007 \\
\hline $\begin{array}{l}\text { contributions } \\
\left(\mathbf{S}_{f}\right)\end{array}$ & 2001 & 0.788 & 0.161 & 0.226 & 0.260 & 0.020 & 0.162 & -0.036 & -0.005 \\
\hline
\end{tabular}

Weighted data from Surveys of Consumer Finances. The reported statistics are corrected for multiple imputation. The sample excludes households with negative net worth. 
Figure 1A. Quantile Regression Decomposition 1998-1989:

Coefficient and Covariate effects

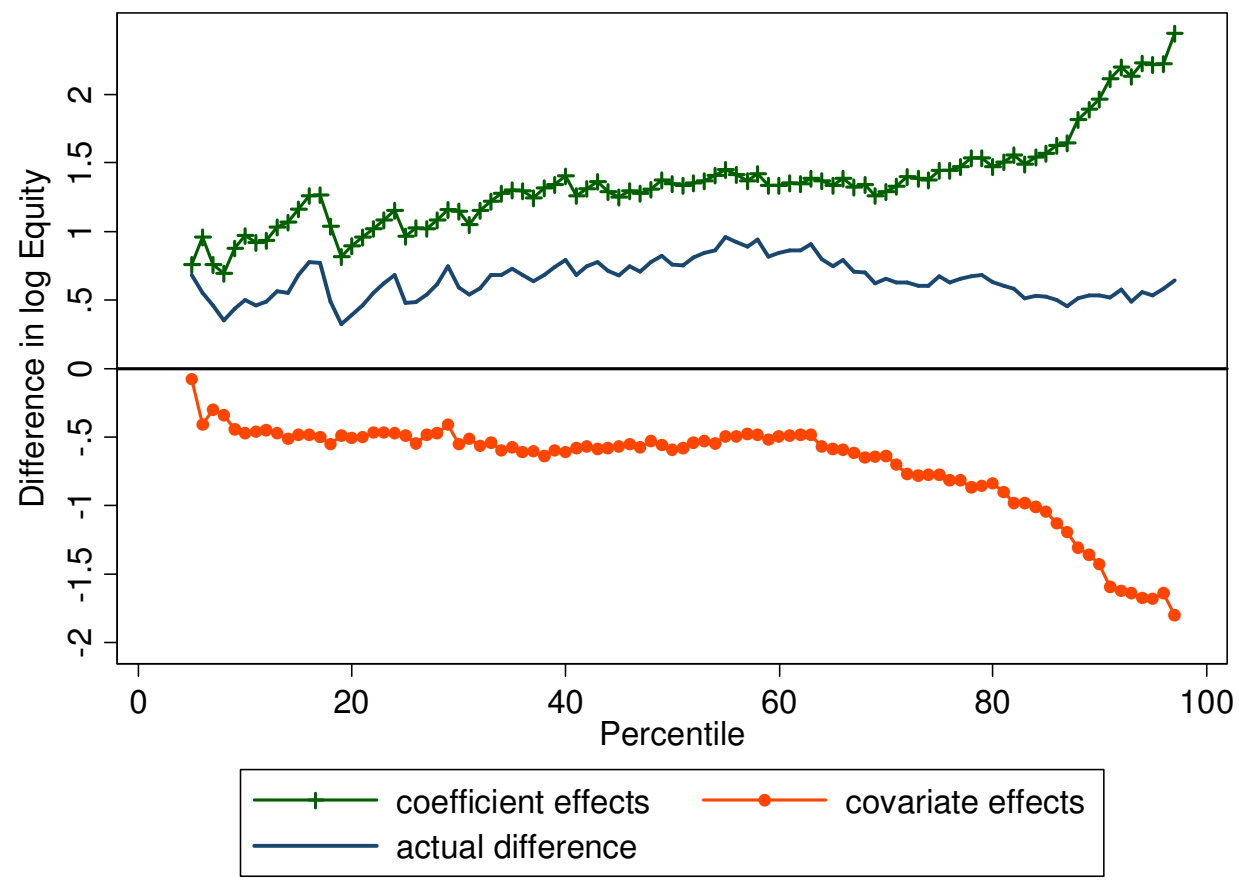

Figure 1B. Quantile Regression Decomposition 1998-1989: Contributions of Fundamentals to Covariate effects

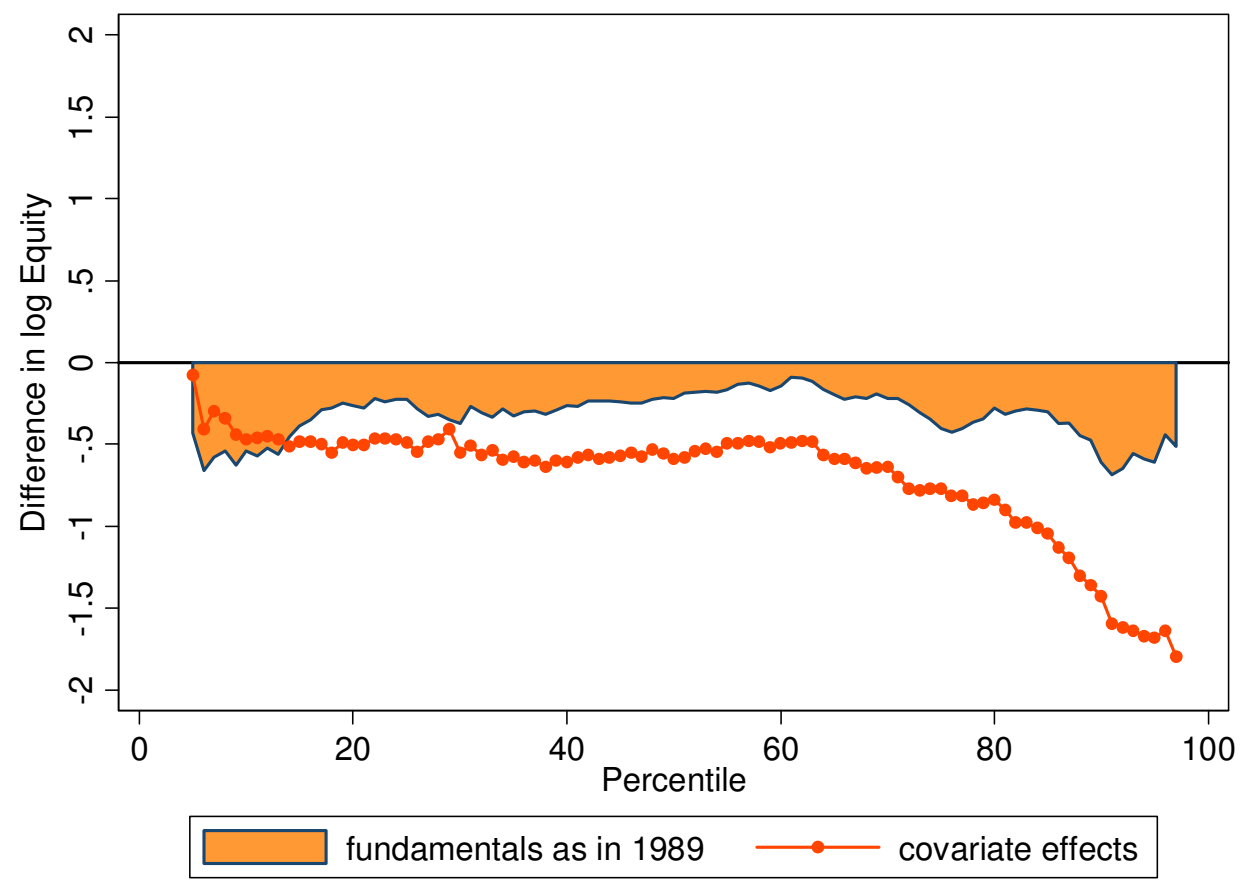


Figure 2A. Quantile Regression Decomposition 2001-1998:

Coefficient and Covariate effects

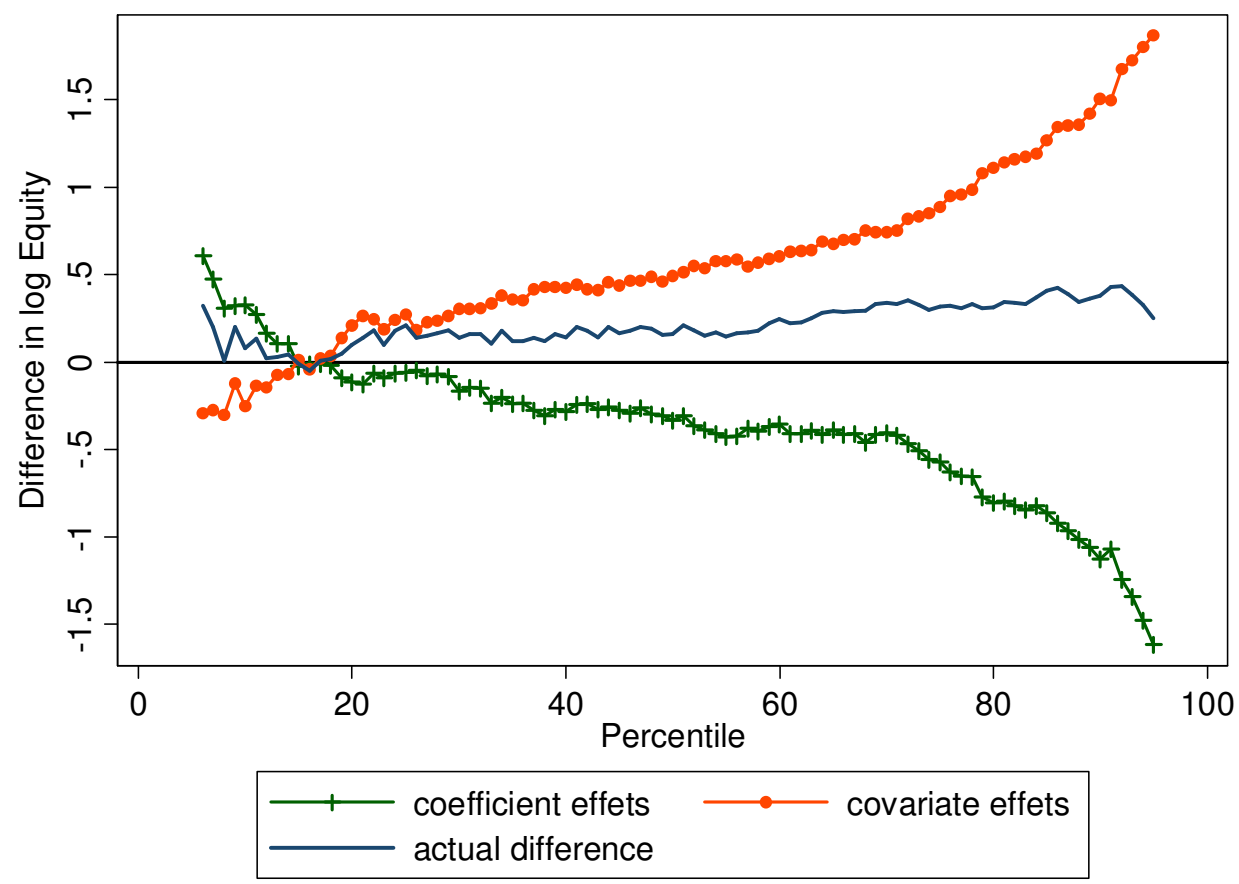

Figure 2B: Quantile Regression Decomposition 2001-1998:

Contributions of Fundamentals to Covariate effects

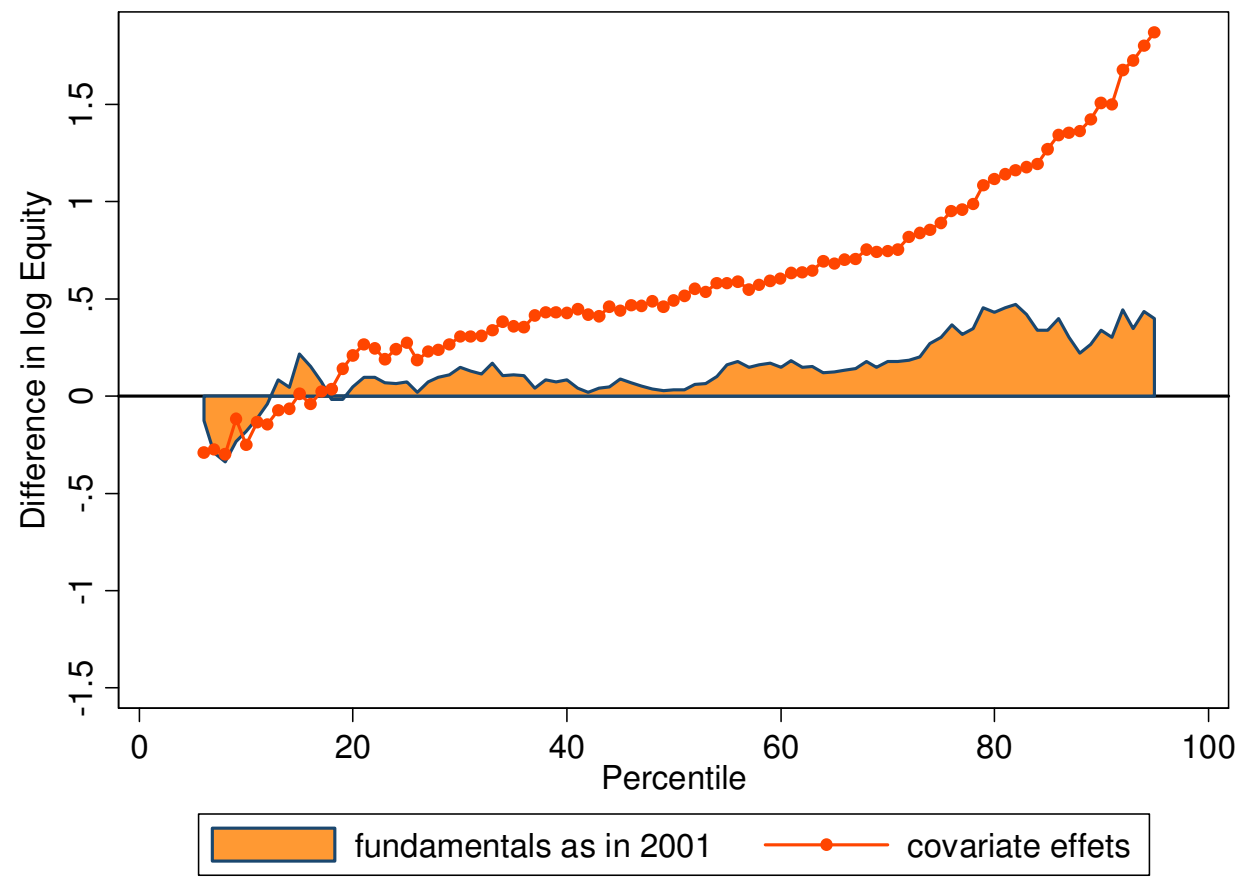

